\title{
CXCR6 and CCR5 Localize T Lymphocyte Subsets in Nasopharyngeal Carcinoma
}

\author{
Greg Parsonage, ${ }^{*}$ Lee Richard Machado, ${ }^{*}$ \\ Jan Wai-Ying Hui, ${ }^{\dagger}$ Andrew McLarnon, ${ }^{*}$ \\ Tilo Schmaler, ${ }^{*}$ Meenarani Balasothy, ${ }^{*}$ Ka-Fai To, ${ }^{\dagger}$ \\ Alexander C. Vlantis, ${ }^{\ddagger}$ Charles A. van Hasselt, ${ }^{\ddagger}$ \\ Kwok-Wai Lo, ${ }^{\dagger}$ Wai-Lap Wong, ${ }^{\S}$ Edwin Pun Hui, ${ }^{\S}$ \\ Anthony Tak Cheung Chan, ${ }^{\S}$ and Steven P. Lee* \\ From the School of Cancer Sciences,* University of Birmingham, \\ Birmingham, United Kingdom; the Departments of Anatomical \\ and Cellular Patbology ${ }^{\dagger}$ and Clinical Oncology, ${ }^{\circledR}$ Sir YK Pao \\ Centre for Cancer, Chinese University of Hong Kong, Hong Kong; \\ and the Department of Otorbinolaryngology, Head and Neck \\ Surgery, ${ }^{\ddagger}$ Chinese University of Hong Kong, Hong Kong
}

The substantial $\mathrm{T}$ lymphocyte infiltrate found in cases of nasopharyngeal carcinoma (NPC) has been implicated in the promotion of both tumor growth and immune escape. Conversely, because malignant NPC cells harbor the Epstein-Barr virus, this tumor is a candidate for virus-specific $T$ cell-based therapies. Preventing the accumulation of tumor-promoting $T$ cells or enhancing the recruitment of tumor-specific cytotoxic $T$ cells offers therapeutic potential. However, the mechanisms involved in $T$ cell recruitment to this tumor are poorly understood. Comparing memory $T$ cell subsets that have naturally infiltrated NPC tissue with their counterparts from matched blood revealed enrichment of $\mathrm{CD8}^{+}, \mathrm{CD4}^{+}$, and regulatory $T$ cells expressing the chemokine receptor CXCR6 in tumor tissue. $\mathrm{CD8}^{+}$and (nonregulatory) $\mathrm{CD}^{+} \mathrm{T}$ cells also were more frequently $\mathrm{CCR} 5^{+}$in tumor than in blood. Ex vivo studies demonstrated that both receptors were functional. CXCL16 and CCL4, unique chemokine ligands for CXCR6 and CCR5, respectively, were expressed by the malignant cells in tumor tissue from the majority of NPC cases, as was another CCR5 ligand, CCL5. The strongest expression of CXCL16 was found on tumor-infiltrating cells. CCL4 was detected on the tumor vasculature in a majority of cases. These findings suggest that CXCR6 and CCR5 play important roles in $T$ cell recruitment and/or retention in NPC and have implications for the pathogenesis and treatment of this tumor. (Am J Pathol 2012, 180:1215-1222; DOI: 10.1016/j.ajpath.2011.11.032)
Undifferentiated nasopharyngeal carcinoma (NPC) is one of the most common cancers in Southeast Asia, with an incidence of up to 28 cases per 100,000 men in regions of southern China. ${ }^{1}$ Radiotherapy alone or with chemotherapy cures the majority of NPC cases, although the proximity of the tumor to radiosensitive organs frequently results in complications that reduce quality of life. ${ }^{2}$ Furthermore, half of all patients present with advanced disease (stage III-IV) where 5-year disease-specific survival rates are only $72 \%{ }^{3}$

The malignant cells of NPC are associated with a sizeable lymphoid stroma mainly consisting of $\alpha / \beta$ TCR $+\mathrm{T}$ cells, ${ }^{4}$ with both $\mathrm{CD}^{+}{ }^{+}$and $\mathrm{CD} 8+$ subsets present in variable proportions. ${ }^{5}$ It has been suggested that these tumor infiltrating lymphocytes (TIL) may be required for tumor growth, possibly through intercellular signaling via CD40 ligand, CD27, and/or CD28 on TIL engaging corresponding receptors/ligands (CD40, CD70, CD80/86) on the malignant cells. ${ }^{5,6}$ Alternatively, TIL may represent an ongoing immune response to the tumor, possibly targeting Epstein-Barr virus (EBV) proteins that are expressed in the malignant cells. ${ }^{7-9}$ However, at least $10 \%$ of NPC TIL are of a regulatory T cell (Treg) phenotype (CD4+CD25highFoxp3+). ${ }^{10}$ Tregs suppress immune responses through cytokine release and/or cell-cell contact and have been detected in many human cancers where they may promote immune escape by tumor cells. ${ }^{11}$

Thus, TIL within NPC may play a role in tumor growth and/or immune escape. Preventing the accumulation of these cells within the tumor could therefore have therapeutic potential. Alternatively, ensuring efficient delivery of tumor-specific cytotoxic T cells from the circulation to the tumor tissue could overcome immune evasion mechanisms and destroy malignant cells. Indeed, NPC is considered a good candidate for $\mathrm{T}$ cell-based therapies and

Supported by grants from Cancer Research UK, including a Senior Cancer Fellowship (S.P.L.) and project grant C489/A9501 (S.P.L.), and a grant from Hong Kong Cancer Fund (A.T.C.C. and E.P.H.)

Accepted for publication November 29, 2011.

G.P. and L.R.M. contributed equally to this work.

Current address of L.R.M.: Department of Genetics, University of Leicester, Leicester, LE1 7RH, United Kingdom.

Address reprint requests to Steven P. Lee, Ph.D., School of Cancer Sciences, University of Birmingham, Edgbaston, Birmingham B15 2TT, United Kingdom. E-mail: s.p.lee@bham.ac.uk. 
clinical trials of adoptive T cell therapy ${ }^{12-14}$ or vaccination $^{15}$ to boost $T$ cell responses to tumor-associated EBV antigens have reported objective clinical responses in some patients.

Preventing accumulation of tumor-promoting TIL or efficiently targeting anti-tumor $\mathrm{T}$ cells to the tumor site requires an understanding of the mechanisms whereby $T$ cells are recruited/retained within NPC tissue. T-cell homing to lymphoid structures and sites of infection/inflammation is an active process. Particular combinations of cell surface molecule interactions are required to enable selective recruitment across vascular endothelium, infiltration and retention of lymphocytes. Cells rolling along the vessel wall must usually encounter specific chemokines to activate integrin adhesion molecules, extravasate, and subsequently position themselves appropriately within the tissue. ${ }^{16}$ Thus, $T$ cells will only be recruited to a tumor if cognate chemokine ligand-receptor interactions can occur.

We have explored the role of chemokine receptors in locating CD8, CD4, and regulatory T cell subsets within NPC tissue and determined the presence of appropriate ligands at the tumor site. We have also explored the implications of these findings for developing T cell-based therapies for NPC.

\section{Materials and Methods}

\section{Blood and Tumor Tissue}

Paired tumor biopsy and heparinized blood samples were obtained from 20 newly diagnosed NPC patients. In addition, samples were taken from two patients undergoing nasopharyngectomy following relapse several years after radiotherapy with or without chemotherapy. Tumor tissue was rinsed with RPMI 1640 (Life Technologies, Paisley, UK) to remove any traces of blood, then finely minced using a scalpel to isolate TIL. Peripheral blood mononuclear cells (PBMC) were isolated from heparinized blood samples by density gradient centrifugation on lymphoprep (Robbins Scientific, Solihull, UK). All TIL and PBMC were cryopreserved (except for migration assays). Blood samples were also collected from healthy EBV carriers. Formalin-fixed, paraffin-embedded tissues $(n=59)$ and snap frozen tissue $(n=9)$ were obtained from additional untreated NPC patients. Ethical approval for this work was granted by the Clinical Research Ethics Committee of the Chinese University of Hong Kong and West Midlands Research Ethics Committee, UK. All donors provided written informed consent before entering the study.

\section{Cell Lines}

THP.1, a monomyelocytic cell line that expresses CCR $5^{17}$, and the NPC cell line c666. $1^{18}$ were cultured in RPMI 1640 supplemented with $10 \%$ fetal bovine serum (FBS), 2 mmol/L L-glutamine, $100 \mu \mathrm{g} / \mathrm{mL}$ streptomycin, and $100 \mathrm{IU} / \mathrm{mL}$ penicillin. The c666.1 was cultured in flasks precoated with fibronectin $(10 \mu \mathrm{g} / \mathrm{mL})$. EBV-specific polyclonal T cell lines were generated as described. ${ }^{19}$

\section{Flow Cytometry}

TIL and PBMC were incubated with anti-CXCR6 (clone 56811; R\&D Systems, Minneapolis, MN), anti-CCR5 (clone 2D7; Becton Dickinson, San Jose, CA), or isotype-matched controls diluted in buffer (PBS containing $2 \%[\mathrm{v} / \mathrm{v}] \mathrm{FBS}$ ). Cells were washed in buffer and then stained with biotinylated anti-mouse IgG (Southern Biotechnology, Birmingham, Alabama), followed by a further wash and stain with streptavidin-fluorophore conjugate (Cambridge Biosciences, Cambridge, UK). Cells were washed and incubated with normal mouse serum (Dako, Glostrup, Denmark) on ice for 20 minutes. Before fixation using a Foxp3 staining buffer set (eBioscience, San Diego, CA), the cells were incubated with saturating concentrations of antibodies specific for CD3, CD4, CD8, CD45RA, and CD25. After permeabilization (according to the manufacturer's instructions), intranuclear staining was performed with anti-Foxp3 or isotypematched control (eBioscience). The median number of Tregs (CD3+CD4+CD45RA-CD25 hi Foxp3+) analyzed were 5000 and 1000 cells from TIL and peripheral blood lymphocytes (PBL), respectively. T cell lines were analyzed using human leukocyte antigen (HLA) class I tetramers generated as described ${ }^{20}$ to detect responses to defined EBV epitopes. ${ }^{21}$ Cells were stained with the relevant tetramer for 10 minutes at $37^{\circ} \mathrm{C}$ then placed on ice for 30 minutes where they were co-stained with antibodies specific for CCR5 or CXCR6 or with isotype-matched controls. Bound antibody was detected using fluorescein isothiocyanate (FITC)-labeled goat anti-mouse antibody (Sigma-Aldrich, St. Louis, $\mathrm{MO}$ ). Cells were then blocked with mouse serum (Dako) and stained with anti-CD8 antibody (Beckman Coulter, Brea, CA). Cells were analyzed using a BD LSR II flow cytometer and FlowJo software (TreeStar Inc, Ashland, OR).

\section{Immunohistochemistry}

Snap frozen tissue was sectioned ( $5 \mu \mathrm{m})$ and fixed in acetone for 10 minutes. Following rehydration in PBS, sections were incubated overnight at $4^{\circ} \mathrm{C}$ with anti-CXCR6 (56811) or isotype-matched antibody control (Dako).

Formalin-fixed paraffin-embedded sections (5 $\mu \mathrm{m})$ were mounted onto vectorbond-coated slides (Vector Laboratories, Peterborough, UK), deparaffinized in $x y$ lene, cleared in $100 \%$ ethanol, and washed briefly in tap water. Endogenous peroxidase was blocked with 3\% hydrogen peroxide in methanol for 10 minutes. Antigen retrieval was achieved by boiling slides for 30 minutes in a microwave (800 W) in $10 \mathrm{mmol} / \mathrm{L}$ citrate buffer ( $\mathrm{pH} 5.8$ ). Sections were rehydrated in PBS and incubated overnight at $4^{\circ} \mathrm{C}$ in PBS with antibodies specific for CCR5, ${ }^{22}$ CXCL16, CCL4, CCL5 (R\&D Systems), or isotype/species-matched antibody controls (Dako).

After washing in PBS monoclonal antibodies were detected using a Dako Envision+ kit (Dako) and polyclonal goat IgG antibodies were detected using peroxidase-conjugated rabbit anti-goat immunoglobulin followed by peroxidase-conjugated goat anti-rabbit immunoglobulin (Dako). Bound antibody was visualized with the 3,3 diaminobenzidine-based detection reaction (Sigma). Images were re- 
corded digitally using brightfield microscopy and a Nikon Coolpix camera (Nikon Corporation, Tokyo, Japan).

\section{Migration Assay}

Fresh TIL or THP. 1 cells in RPMI- 1640 with $0.1 \%$ BSA (assay media) were added to the top chamber of a 3- $\mu \mathrm{m}$ pore HTS-Transwell-96 (Corning Inc, Corning, NY) or 3- $\mu \mathrm{m}$ transwell filter (6.5-mm diameter; Appleton Woods, Birmingham, UK) and conditioned supernatant or assay media containing recombinant chemokine added to the lower chamber. Transwells were incubated at $37^{\circ} \mathrm{C} / 5 \%$ $\mathrm{CO}_{2}$ for 4 hours, then medium removed from the lower chamber and migrated cells counted by flow cytometry using Flow-Count beads (Beckman Coulter). Background migration was assessed using RPMI-1640 containing 1\% FBS or assay media alone as a stimulus. Recombinant human chemokines (R\&D Systems) were used at pretitered concentrations to achieve maximal migration of lymphocytes. Conditioned supernatant from an NPC line was obtained by culturing c666. 1 cells for 3 days at $37^{\circ} \mathrm{C} / 5 \%$ $\mathrm{CO}_{2}$ in RPMI-1640 containing 1\% FBS. Supernatant was then centrifuged to remove cell debris and filtered $(0.45$ $\mu \mathrm{m})$. In some experiments supernatants were preincubated for 30 minutes at $37^{\circ} \mathrm{C}$ with a CCL5-specific blocking antibody or normal goat IgG control (R\&D systems).

\section{ELISA}

CCL5 and CXCL16 levels secreted by the NPC cell line c666.1 were measured using DuoSet ELISA kits (R\&D Systems) according to the manufacturer's instructions.

\section{Results}

\section{Enrichment of $\mathrm{CXCR}^{+}$and $\mathrm{CCR} 5^{+} \mathrm{CD} 4$ and CD8 T Cells Within NPC Tissue}

To identify molecules implicated in $\mathrm{T}$ cell recruitment to NPC, we compared the expression of chemokine receptors on NPC TIL and matched PBMC. Receptors overexpressed on TIL compared with matched PBMC are likely to be involved in recruitment and/or retention of T cells within the tumor tissue. Using multicolor flow cytometry, TIL and PBMC from 22 NPC cases were co-stained with antibodies specific for CD4, CD8, CD45RA, and a range
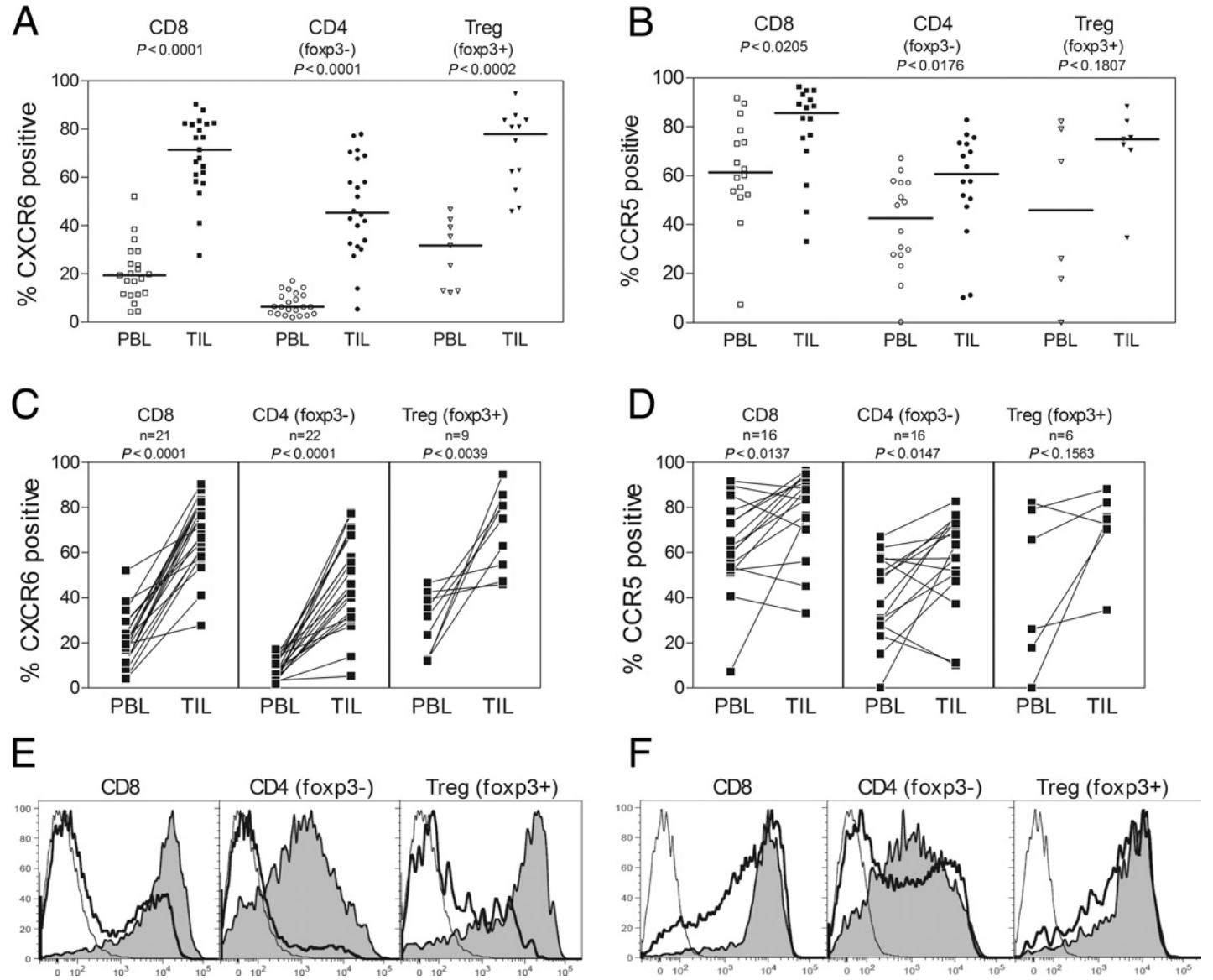

Figure 1. CXCR6 and CCR5 expression on peripheral blood and tissue infiltrating lymphocytes. T cells were isolated from the blood (peripheral blood lymphocytes [PBL]) and tumor tissue (tumor infiltrating lymphocytes [TIL]) of nasopharyngeal carcinoma cases and multicolor flow cytometry used to determine the proportions of memory $\mathrm{CD}^{+}\left(\mathrm{CD}^{+} \mathrm{CD}^{+} \mathrm{CD} 45 \mathrm{RA}^{-}\right), \mathrm{CD}^{+}$nonregulatory $\mathrm{T}$ cells (non-Tregs) $\left(\mathrm{CD} 3^{+} \mathrm{CD} 4^{+} \mathrm{CD} 45 \mathrm{RA}^{-} \mathrm{Foxp}^{-}\right.$) and $\mathrm{Tregs}^{-}$ $\left(\mathrm{CD}^{+} \mathrm{CD}^{+} \mathrm{CD} 4 \mathrm{RA}^{-} \mathrm{CD} 25^{\text {hi }}\right.$ Foxp $\left.3^{+}\right)$expressing chemokine receptors (A) CXCR6 or $(\mathbf{B})$ CCR5. Data from each patient were corrected for nonspecific staining measured using isotype-matched antibody controls. Statistical significance of differences was determined using the Mann-Whitney test ( $P$ values shown). C-D: Matched pair analysis for which the Wilcoxon matched pairs test was used. E-F: Representative plots of CXCR6 and CCR5 staining respectively on TIL (shaded) and matched PBL (thick line, not shaded) with concentration-matched isotype control staining shown with a thin line. 
of chemokine receptors. CD45RA was included to ensure that TIL, which were almost entirely of a CD45RA-negative (memory) phenotype (data not shown), were only compared with memory cells in the blood. Numbers of TIL recovered from NPC biopsies was often small, restricting the numbers of chemokine receptors that could be analyzed. Therefore following the clearest indications of selective enrichment from preliminary data, we focused on two receptors, CXCR6 and CCR5. CXCR6 was expressed on a greater proportion of memory CD8+ T cells in the tumor than in the blood (median $=71.5 \%$ versus $19.4 \%, P<0.0001$ ) and the same was true for memory nonregulatory (Foxp3-) $\mathrm{CD}^{+} \quad \mathrm{T}$ cells $($ median $=44.3 \%$ versus $6.3 \%, P<0.0001)($ Figure $1 \mathrm{~A})$. Interestingly, CXCR6 was also expressed on a greater proportion of tumor-infiltrating memory $\mathrm{CD} 4^{+} \mathrm{CD} 25^{\text {high }} \mathrm{Foxp}^{+}$ Tregs than their circulating counterparts (median $=77.9 \%$ versus $31.7 \%, P=0.0002$ ) (Figure $1 \mathrm{~A}$ ). CCR5 was consistently expressed on a greater proportion of both memory CD8 $+\mathrm{T}$ cells $($ median $=85.7 \%$ versus $61.4 \%, P=0.0205)$ and memory $\mathrm{CD}^{+}{ }^{+} \mathrm{T}$ cells (median $=60.6 \%$ versus $42.6 \%$, $P=0.0176)$ in the tumor than in the blood (Figure 1B). These findings were confirmed when restricting the analysis to TIL and circulating memory T cells from matched pairs of tumor and blood samples (Figure 1, C and D).

\section{CXCR6 and CCR5 Expression on TIL}

To explore the distribution of CXCR6 and CCR5 within NPC tissue, sections were stained with antibodies specific for CXCR6 (Figure 2A) and CCR5 (Figure 2B). Both receptors were widely distributed on a majority of lymphocytes both surrounding and within the tumor nests. Neither chemokine receptor was detected on malignant cells.

\section{Expression of CXCR6 and CCR5 Ligands in NPC}

Tissue sections from NPC biopsies were firstly stained using antibodies specific for CXCL16 and CCL4; unique chemoattractant ligands for CXCR6 and CCR5, respectively. Malignant cells varied in their intensity of CXCL16 expression (19 out of 27 cases positive) and vascular endothelial structures were generally CXCL16-negative (only 1 out of 25 cases showed significant staining). Interestingly, CXCL16 was strongly expressed by intra- and peritumoral mononuclear cells. This was a consistent finding in 26 out of 27 cases analyzed (Figure 2C).

Tumor cells in 23 out of 33 cases stained positively for CCL4 (Figure 2D). Furthermore, this unique CCR5 ligand could be detected more readily on endothelia lining the tumor vasculature (15 out of 27 cases) (Figure 2, D and E).

Although CCL4 only signals through CCR5, this receptor is capable of transducing a signal in response to other chemokine ligands. One such ligand, CCL5, was found at widely varying levels on NPC tumor cells in 13/17 cases (Figure 2F). As shown in the figure, some infiltrating lymphocytes also expressed CCL5.
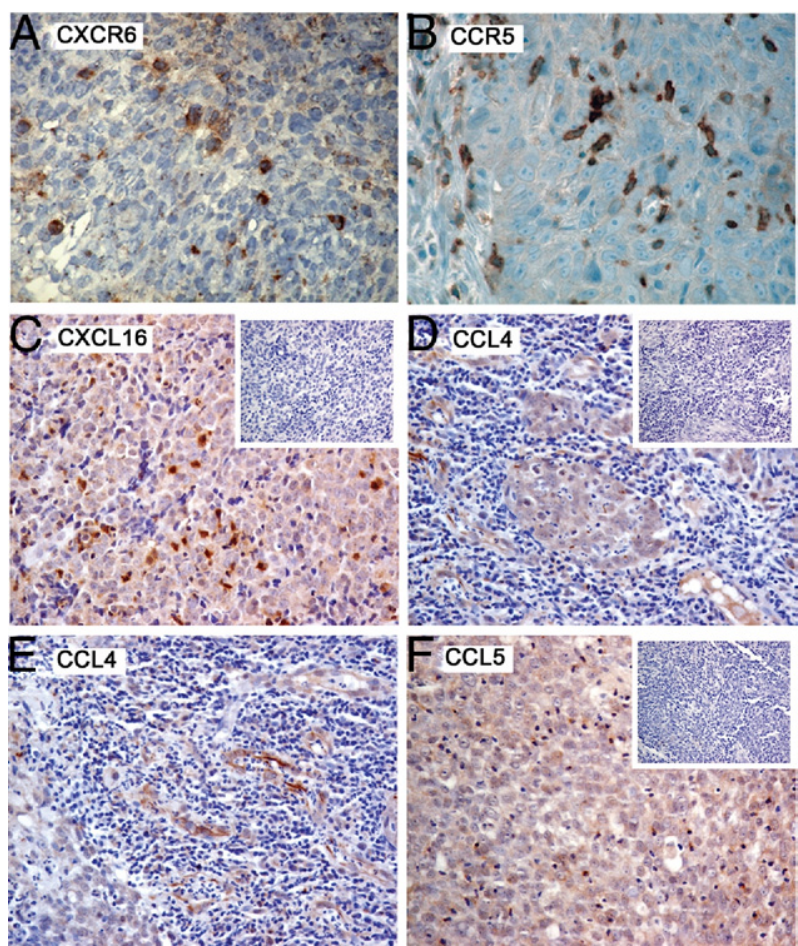

Figure 2. Chemokine and chemokine receptor expression in nasopharyngeal carcinoma (NPC). NPC tissues were examined by immunohistochemistry for expression of the indicated chemokine receptors or chemokines. $\mathbf{A}-\mathbf{F}$ : Representative staining from NPC cases is shown for CXCR6 $(n=9)$, CCR5 $(n=9), \operatorname{CXCL16}(n=27), \operatorname{CCL} 5(n=17)$, and CCL4 $(n=33)$. Concentrationmatched isotype control stains are shown as insets.

\section{CXCR6 and CCR5 Function on NPC TIL}

To determine whether CXCR6 and CCR5 on infiltrating T cells are functional, TIL from four freshly biopsied NPC cases were tested in migration assays using unique ligands for each receptor. As shown in Figure 3, migratory responses to soluble CXCR6 or CCR5 ligands could be measured in all four patients tested. In two cases, migration occurred in response to both chemokines, and in the remaining cases, migration was observed in response to CXCL16 or CCL4.

\section{NPC Cell Line c666.1 Secretes CXCL16 and Functional CCL5}

We further explored the expression and function of CXCR6 and CCR5 ligands in NPC using the c666.1 cell line. ELISAs performed on c666.1 supernatants showed that both CXCL16 and CCL5 were secreted in biologically relevant (nanograms per milliliter) amounts (Figure 4A). CCL5 secretion was also confirmed by Western blotting (data not shown). Using transwell migration assays, we tested the ability of conditioned supernatant from c666.1 to induce migration of CCR5 ${ }^{+}$THP.1 cells. As shown in Figure 4, B-D, THP.1 cells migrated in a dosedependent manner to both recombinant CCL5 and conditioned supernatant, and this was abrogated using a CCL5-specific blocking antibody. 


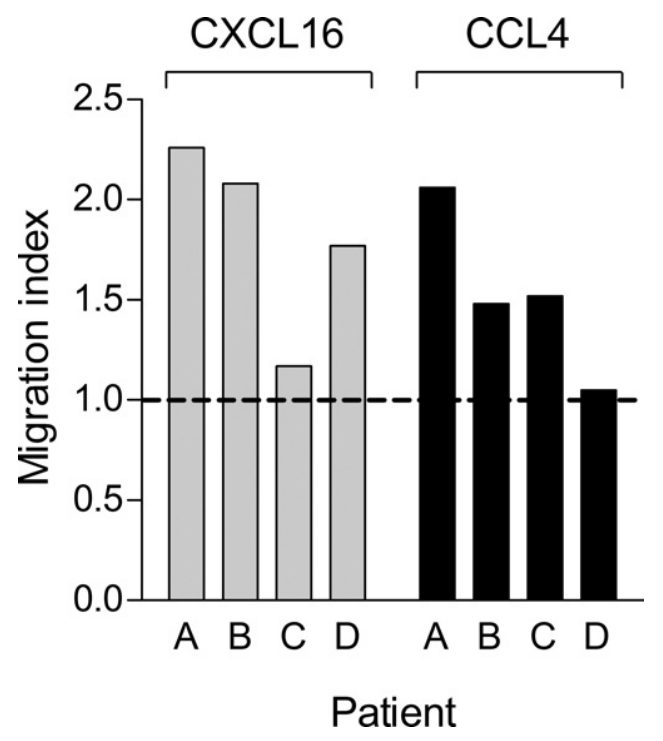

Figure 3. Functional test of CXCR6 and CCR5 on freshly isolated tumor infiltrating lymphocytes. Infiltrating lymphocytes from four patients' diagnostic nasopharyngeal carcinoma biopsies (designated $\mathbf{A}, \mathbf{B}, \mathbf{C}$, and $\mathbf{D}$ ) were placed in porous transwell inserts (3- $\mu \mathrm{m}$ pore size) and presented with a gradient of the indicated chemokine CXCL16 (CXCR6 ligand) or CCL4 (CCR5 ligand) (10 ng/mL) or control medium. Migration index was calculated by dividing the numbers of $\mathrm{T}$ cells migrating in response to chemokine by the number migrating in response to medium alone.

\section{CXCR6 and CCR5 Expression on EBV-Specific $T$ Cells Generated in Vitro}

EBV-specific polyclonal T cell lines reactivated and expanded in vitro for several weeks using autologous EBVtransformed Lymphoblastoid cell lines (LCLs) can be in- fused to treat $\mathrm{EBV}^{+}$posttransplant lymphoproliferative disease. ${ }^{23}$ These have also mediated clinical responses in some NPC patients. ${ }^{12-14}$ To explore the homing phenotype of EBV-specific $T$ cells generated using this protocol we performed a kinetic analysis of CXCR6 and CCR5 expression by flow cytometry. Cells were costained with HLA:peptide tetramers to identify EBV-specific $T$ cells (including those specific for viral proteins expressed in NPC). Before stimulation with the LCL, EBVspecific $T$ cells were detectable in PBMC from three donors. CCR5 was expressed on $>90 \%$ of these cells and expression was retained throughout the culture period as these $T$ cell responses expanded following $L C L$ stimulation. For two out of three donors CXCR6 was expressed on $<20 \%$ of detectable EBV-specific T cells in PBMC. However, after LCL stimulation and 2 to 4 weeks of culture, $>50 \%$ of detectable EBV-specific T cells were CXCR6-positive and this phenotype was again maintained (Figure 5). As other EBV-specific T cell responses emerged in these cultures, they also stably expressed these receptors. These results indicate that EBV-specific $T$ cells reactivated and expanded using current protocols display an appropriate homing phenotype to target NPC.

\section{Discussion}

In this study, we sought to determine which chemokine receptors play an active role in localizing T cells to NPC tumors because this could identify mechanisms to reduce the numbers of tumor-promoting T cells and/or improve the efficacy of cytotoxic T cell-based therapies. A handful of earlier immunohistochemistry studies have reported expression of some chemokines and their recep-
A

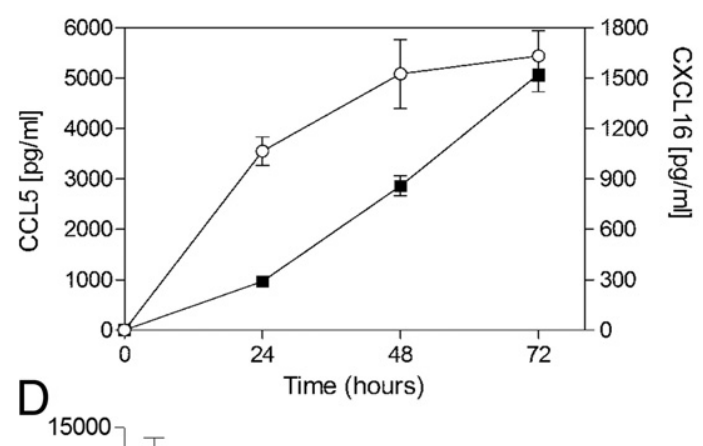

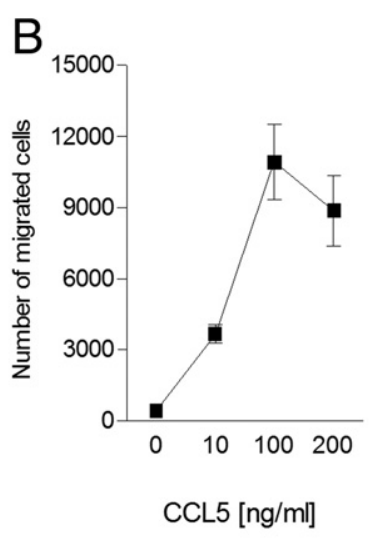

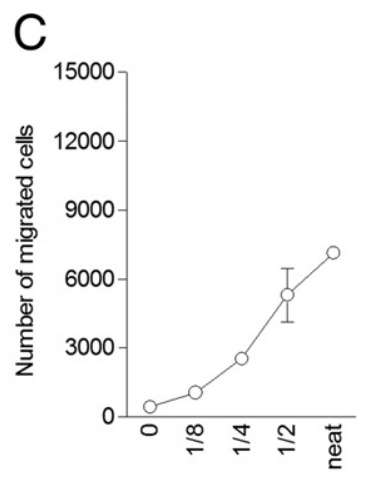

c666. 1 supernatant titre

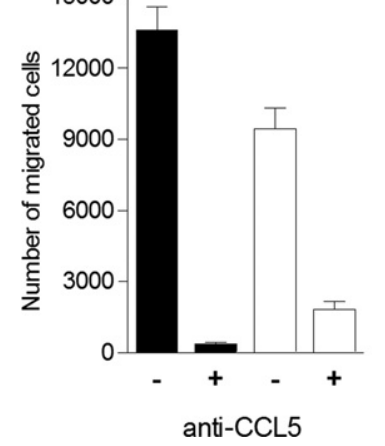

Figure 4. Functional chemokine secretion by a nasopharyngeal carcinoma (NPC) tumor cell line. A: Concentrations of CCL5 (open circles) and CXCL16 (filled squares) secreted by the NPC cell line c666.1 over a 72-hour period were measured by enzyme-linked immunosorbent assay. B: Dose-response curve showing chemotaxis of a CCR5 positive cell line (THP.1) in response to recombinant CCL5 or (C) c666.1-conditioned supernatants. D: shows THP.1 chemotaxis in response to $100 \mathrm{ng} / \mathrm{mL}$ recombinant CCL5 (filled bars) or neat conditioned medium from c666.1 cells (open bars), measured either in the presence of a negative control goat IgG or blocking antibody to CCL5 $(5 \mu \mathrm{g} / \mathrm{mL})$ as indicated. Data represent the mean of duplicate tests \pm SD 

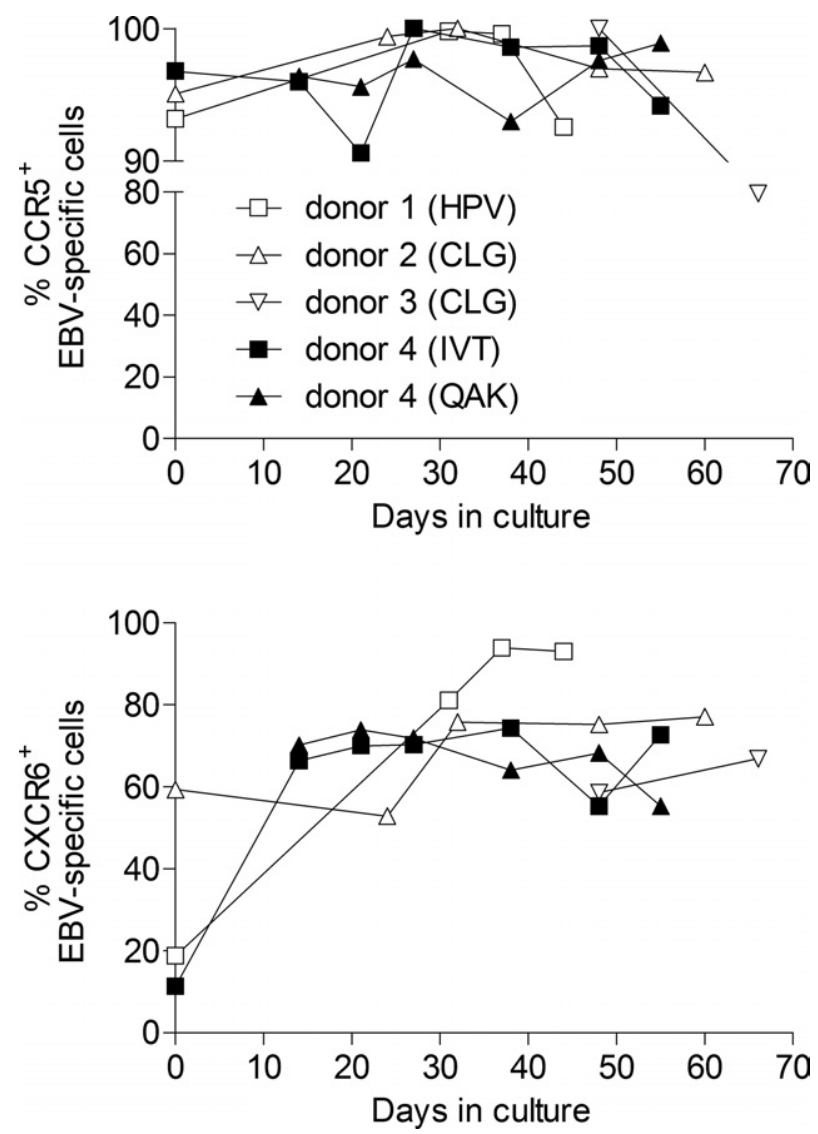

Figure 5. CCR5 and CXCR6 expression on in vitro expanded EBV-specific T cell lines. EBV-specific T cell lines from healthy virus carriers were generated in vitro following stimulation with the autologous lymphoblastoid cell line. The expression of CCR5 and CXCR6 on EBV-specific CD8+ T cells (detected using human leukocyte antigen (HLA):peptide tetramers) was assessed by flow cytometry at various time points during the in vitro culture period. The HLA:peptide tetramers stained T cells specific for the following EBV antigens: CLG, HLA A*0201-restricted epitope in latent membrane protein-2 (sequence CLGGLLTMV); "HPV", HLA B*3501-restricted epitope in Epstein-Barr virus nuclear antigen-1 (sequence HPVGEADYFEY); "QAK", HLA B*0801-restricted epitope in EBNA-3A (sequence QAKWRLQTL); "IVT", HLA A*1101-restricted epitope in EBNA-3B (sequence IVTDFSVIK).

tors within the NPC tumor environment, including some of those detailed here. However, ours is the first study to describe and quantitate an enrichment of $T$ cells expressing CXCR6 and CCR5 at the tumor site. Furthermore, we were able to demonstrate the functionality of these receptors on primary cells ex vivo.

CXCR6 has a single ligand, CXCL16, which can exist in membrane bound or soluble forms, the latter requiring cleavage from the membrane by a disintegrin and metalloproteinase domain-10 or a disintegrin and metalloproteinase domain-17. ${ }^{24-26}$ In addition to chemotaxis, CXCL16 has been shown to mediate adhesion and phosphatidyl serine/oxidized low-density lipoprotein scavenger receptor functions, ${ }^{27,28}$ and can be expressed in lymph nodes, lung, and liver tissues.27,29 We found infiltrating mononuclear cells to be an abundant source of CXCL16 in NPC tumors (Figure 2C). CXCL16 was also detected on tumor cells in 19 out of 27 cases and we have shown that the c666. 1 cell line secretes biologically relevant quantities of this chemokine in soluble form (Figure 4A). Thus, this chemokine may mediate recruitment and/or retention of $\mathrm{CXCR}^{+} \mathrm{T}$ cells into the NPC tumor microenvironment following extravasation. High levels of CXCL16 expression on colorectal and renal cell carcinoma cells have been reported to correlate with favorable prognoses. ${ }^{30,31}$ It would be interesting to know whether a similar association exists in NPC. Because ionizing radiation appears to increase the expression of CXCL16 in tumor cells, ${ }^{32}$ it might be advantageous to follow standard local radiotherapy with an immediate infusion of $\mathrm{CXCR6}^{+} \mathrm{EBV}$ specific $\mathrm{T}$ cells.

Our data on CCR5 expression have substantially extended observations first made by Tang et al. ${ }^{33}$ Although they reported the presence of infiltrating leukocytes expressing CCR5 in 12 out of 15 cases, the identity of these cells was not determined. We have shown that CCR5 ${ }^{+}$ cells are consistently present in all infiltrating $T$ cell subsets examined $\left(\mathrm{CD}^{+}, \mathrm{CD} 4^{+}\right.$, and Treg). Furthermore, we found that significant enrichment of $\mathrm{CD}^{+} \mathrm{CCR} 5^{+}$and nonregulatory $\mathrm{CD} 4{ }^{+} \mathrm{CCR} 5{ }^{+} \mathrm{T}$ cells occurs at the tumor site. Unlike CXCR6, CCR5 can receive signals from multiple chemokine ligands. In contrast to a previous report, ${ }^{33}$ we observed one such ligand, CCL5, on tumor cells, albeit at varying levels in 13 out of 17 cases, and also on some infiltrating lymphocytes. In this context, it is noteworthy that we were able to demonstrate that functional CCL5 was also secreted constitutively from the EBV-positive NPC cell line c666.1 (Figure 4). CCL5 may therefore promote motility of $T$ cells once within the tissue interstitium. Consistent staining of another shared CCR5 ligand, CCL3, was reported previously on tumor-associated macrophages in NPC. ${ }^{33}$ The same study briefly mentioned that other CCR5 ligands, CCL8 and CCL4, could be found in some NPC cases. Again, our findings agree with, and extend this previous work (Figure 2, D and E). Clearly the location of chemokines within a microenvironment may be critical to their function. Our data suggests that CCL4 may be expressed not only by tumor cells but also vascular endothelia, and therefore may act to select $\mathrm{T}$ cells at the point of tissue entry. The fact that CCL4 binds only to CCR5 underlines the potential importance of this receptor in selective recruitment of $\mathrm{T}$ cells to NPC tumors from the circulation.

Identifying chemokine receptors involved in localizing T cells to the tumor can aid the development of therapies in two ways. First, it identifies a tumor-homing phenotype required on effector cells generated for $T$ cell-based therapies. Second, with the development of chemokine receptor antagonists, there is the potential to prevent enrichment of tumor-promoting $\mathrm{T}$ cells such as Tregs. Our data suggest that EBV-specific T cells, generated in vitro for adoptive therapy or in vivo through vaccination, require expression of CXCR6 and CCR5 for optimal tumor targeting. Encouragingly, we found that current protocols using an LCL to reactivate EBV-specific T cells for adoptive therapy are likely to deliver effectors expressing both CXCR6 and CCR5. As new protocols are developed for generating therapeutic $T$ cells, including the use of genetically engineered $\mathrm{T}$ lymphocytes cultured with alternative cytokines, ${ }^{34}$ it will be important to determine whether expression of these chemokine receptors is maintained. Our data suggest CXCR6 is also involved in localizing Tregs to NPC and therefore a CXCR6/CXCL16 antagonist 
could reduce Treg infiltration of this tumor. However, such an approach would not be selective for Tregs because our data show that other $T$ cell subsets (which might include anti-tumor responses) are also enriched in NPC tissue through this pathway. Nevertheless, alternative mechanisms of T cell recruitment may exist in NPC and could be explored for selective blockade of Tregs. For example, this tumor expresses CCL20, ${ }^{35}$ a chemokine implicated in Treg recruitment to several other human cancers. ${ }^{36-39}$

\section{Acknowledgments}

We thank Martin Larsen and Mathias Mack for contributing reagents for this study.

\section{References}

1. Curado MP, Edwards B, Shin HR, Storm H, Ferlay J, Heanue M, Boyle $P$ (Eds): Cancer Incidence in Five Continents. Volume IX. IARC Scientific Publication No. 160. Lyon Cedex, France: International Agency for Research on Cancer, 2007

2. Wei WI, Sham JS: Nasopharyngeal carcinoma, Lancet 2005, 365: 2041-2054

3. Lee AW, Sze WM, Au JS, Leung SF, Leung TW, Chua DT, Zee BC, Law SC, Teo PM, Tung SY, Kwong DL, Lau WH: Treatment results for nasopharyngeal carcinoma in the modern era: the Hong Kong experience. Int J Radiat Oncol Biol Phys 2005, 61:1107-1116

4. Ferradini L, Miescher S, Stoeck M, Busson P, Barras C, Cerf-Bensussan N, Lipinski M, von Fliedner V, Tursz T: Cytotoxic potential despite impaired activation pathways in T lymphocytes infiltrating nasopharyngeal carcinoma. Int J Cancer 1991, 47:362-370

5. Agathanggelou A, Niedobitek G, Chen R, Nicholls J, Yin W, Young LS: Expression of immune regulatory molecules in Epstein-Barr virusassociated nasopharyngeal carcinomas with prominent lymphoid stroma: evidence for a functional interaction between epithelial tumour cells and infiltrating lymphoid cells. Am J Pathol 1995, 147: $1152-1160$

6. Sbih-Lammali F, Clausse B, Ardila-Osorio H, Guerry R, Talbot M, Havouis S, Ferradini L, Bosq J, Tursz T, Busson P: Control of apoptosis in Epstein Barr virus-positive nasopharyngeal carcinoma cells: opposite effects of CD95 and CD40 stimulation. Cancer Res 1999, 59:924-930

7. Li J, Zeng XH, Mo HY, Rolen U, Gao YF, Zhang XS, Chen QY, Zhang L, Zeng MS, Li MZ, Huang WL, Wang XN, Zeng YX, Masucci MG: Functional inactivation of EBV-specific T-lymphocytes in nasopharyngeal carcinoma: implications for tumor immunotherapy. PLoS One 2007, 2:e1122

8. Lee SP, Tierney RJ, Thomas WA, Brooks JM, Rickinson AB: Conserved CTL epitopes within EBV latent membrane protein 2 - A potential target for CTL-based tumor therapy. J Immunol 1997, 158: 3325-3334

9. Lee SP, Brooks JM, Al Jarrah H, Thomas WA, Haigh TA, Taylor GS, Humme S, Schepers A, Hammerschmidt W, Yates JL, Rickinson AB, Blake NW: CD8 T cell recognition of endogenously expressed Epstein-Barr virus nuclear antigen 1. J Exp Med 2004, 199:1409-1420

10. Lau KM, Cheng SH, Lo KW, Lee SA, Woo JK, van Hasselt CA, Lee $\mathrm{SP}$, Rickinson $\mathrm{AB}, \mathrm{Ng} \mathrm{MH}$ : Increase in circulating Foxp3+ $\mathrm{CD} 4+\mathrm{CD} 25$ (high) regulatory $T$ cells in nasopharyngeal carcinoma patients. Br J Cancer 2007, 96:617-622

11. Zou W: Regulatory T cells, tumour immunity and immunotherapy. Nat Rev Immunol 2006, 6:295-307

12. Comoli P, Pedrazzoli P, Maccario R, Basso S, Carminati O, Labirio M, Schiavo R, Secondino S, Frasson C, Perotti C, Moroni M, Locatelli F, Siena S: Cell therapy of stage IV nasopharyngeal carcinoma with autologous Epstein-Barr virus-targeted cytotoxic $T$ lymphocytes. J Clin Oncol 2005, 23:8942-8949

13. Straathof KC, Bollard CM, Popat U, Huls MH, Lopez T, Morriss MC, Gresik MV, Gee AP, Russell HV, Brenner MK, Rooney CM, Heslop HE:
Treatment of nasopharyngeal carcinoma with Epstein-Barr virus-specific T lymphocytes. Blood 2005, 105:1898-1904

14. Louis CU, Straathof K, Bollard CM, Ennamuri S, Gerken C, Lopez TT, Huls MH, Sheehan A, Wu MF, Liu H, Gee A, Brenner MK, Rooney CM, Heslop HE, Gottschalk S: Adoptive transfer of EBV-specific T cells results in sustained clinical responses in patients with locoregional nasopharyngeal carcinoma. J Immunother 2010, 33:983-990

15. Lin CL, Lo WF, Lee TH, Ren Y, Hwang SL, Cheng YF, Chen CL, Chang YS, Lee SP, Rickinson AB, Tam PK: Immunization with Epstein-Barr Virus (EBV) peptide-pulsed dendritic cells induces functional CD8+ T-cell immunity and may lead to tumor regression in patients with EBV-positive nasopharyngeal carcinoma. Cancer Res 2002, 62: 6952-6958

16. Bromley SK, Mempel TR, Luster AD: Orchestrating the orchestrators: chemokines in control of T cell traffic. Nat Immunol 2008, 9:970-980

17. Schols D, Struyf S, Van Damme J, Este JA, Henson G, De Clercq E: Inhibition of T-tropic HIV strains by selective antagonization of the chemokine receptor CXCR4. J Exp Med 1997, 186:1383-1388

18. Cheung ST, Huang DP, Hui ABY, Lo KW, Ko CW, Tsang YS, Wong N, Whitney BM, Lee JCK: Nasopharyngeal carcinoma cell line (c666-1) consistently harbouring Epstein-Barr virus. Int J Cancer 1999, 83: $121-126$

19. Rooney CM, Smith CA, Ng CC, Loftin SK, Sixbey JW, Gan YJ, Srivastava DK, Bowman LC, Krance RA, Brenner MK, Heslop HE: Infusion of cytotoxic $T$ cells for the prevention and treatment of EpsteinBarr virus-induced lymphoma in allogeneic transplant recipients. Blood 1998, 92:1549-1555

20. Hislop AD, Annels NE, Gudgeon NH, Leese AM, Rickinson AB: Epitope-specific evolution of human CD8(+) T cell responses from primary to persistent phases of Epstein-Barr virus infection. J Exp Med 2002, 195:893-905

21. Hislop AD, Taylor GS, Sauce D, Rickinson AB: Cellular responses to viral infection in humans: lessons from Epstein-Barr virus. Annu Rev Immunol 2007, 25:587-617

22. Mack M, Luckow B, Nelson PJ, Cihak J, Simmons G, Clapham PR, Signoret N, Marsh M, Stangassinger M, Borlat F, Wells TN, Schlondorff D, Proudfoot AE: Aminooxypentane-RANTES induces CCR5 internalization but inhibits recycling: a novel inhibitory mechanism of HIV infectivity. J Exp Med 1998, 187:1215-1224

23. Heslop HE, Slobod KS, Pule MA, Hale GA, Rousseau A, Smith CA, Bollard CM, Liu H, Wu MF, Rochester RJ, Amrolia PJ, Hurwitz JL, Brenner MK, Rooney CM: Long-term outcome of EBV-specific T-cell infusions to prevent or treat EBV-related lymphoproliferative disease in transplant recipients. Blood 2010, 115:925-935

24. Matloubian M, David A, Engel S, Ryan JE, Cyster JG: A transmembrane CXC chemokine is a ligand for HIV-coreceptor Bonzo. Nat Immunol 2000, 1:298-304

25. Abel S, Hundhausen C, Mentlein R, Schulte A, Berkhout TA, Broadway N, Hartmann D, Sedlacek R, Dietrich S, Muetze B, Schuster B, Kallen KJ, Saftig P, Rose-John S, Ludwig A: The transmembrane CXC-chemokine ligand 16 is induced by IFN-gamma and TNF-alpha and shed by the activity of the disintegrin-like metalloproteinase ADAM10. J Immunol 2004, 172:6362-6372

26. Ludwig A, Schulte A, Schnack C, Hundhausen C, Reiss K, Brodway $\mathrm{N}$, Held-Feindt J, Mentlein R: Enhanced expression and shedding of the transmembrane chemokine CXCL16 by reactive astrocytes and glioma cells. J Neurochem 2005, 93:1293-1303

27. Shimaoka T, Kume N, Minami M, Hayashida K, Kataoka H, Kita T, Yonehara S: Molecular cloning of a novel scavenger receptor for oxidized low density lipoprotein. SR-PSOX, on macrophages, J Biol Chem 2000, 275:40663-40666

28. Shimaoka T, Nakayama T, Fukumoto N, Kume N, Takahashi S, Yamaguchi J, Minami M, Hayashida K, Kita T, Ohsumi J, Yoshie O, Yonehara S: Cell surface-anchored SR-PSOX/CXC chemokine ligand 16 mediates firm adhesion of CXC chemokine receptor 6-expressing cells. J Leukoc Biol 2004, 75:267-274

29. Wilbanks A, Zondlo SC, Murphy K, Mak S, Soler D, Langdon P, Andrew DP, Wu L, Briskin M: Expression cloning of the STRL33/ BONZO/TYMSTRligand reveals elements of CC. CXC, and CX3C chemokines. J Immunol 2001, 166:5145-5154

30. Gutwein P, Schramme A, Sinke N, Abdel-Bakky MS, Voss B, Obermuller N, Doberstein K, Koziolek M, Fritzsche F, Johannsen M, Jung K, Schaider H, Altevogt P, Ludwig A, Pfeilschifter J, Kristiansen G: Tumoural CXCL16 expression is a novel prognostic marker of longer 
survival times in renal cell cancer patients. Eur J Cancer 2009, 45:478-489

31. Hojo S, Koizumi K, Tsuneyama K, Arita Y, Cui Z, Shinohara K, Minami T, Hashimoto I, Nakayama T, Sakurai H, Takano Y, Yoshie O, Tsukada K, Saiki I: High-level expression of chemokine CXCL16 by tumor cells correlates with a good prognosis and increased tumor-infiltrating lymphocytes in colorectal cancer. Cancer Res 2007, 67:4725-4731

32. Matsumura S, Demaria S: Up-regulation of the pro-inflammatory chemokine CXCL16 is a common response of tumor cells to ionizing radiation. Radiat Res 2010, 173:418-425

33. Tang KF, Tan SY, Chan SH, Chong SM, Loh KS, Tan LK, Hu H: A distinct expression of CC chemokines by macrophages in nasopharyngeal carcinoma: implication for the intense tumor infiltration by $T$ lymphocytes and macrophages. Hum Pathol 2001, 32:42-49

34. June $\mathrm{CH}$, Blazar BR, Riley JL: Engineering lymphocyte subsets: tools, trials and tribulations. Nat Rev Immunol 2009, 9:704-716

35. Chang KP, Hao SP, Chang JH, Wu CC, Tsang NM, Lee YS, Hsu CL, Ueng SH, Liu SC, Liu YL, Wei PC, Liang Y, Chang YS, Yu JS: Macrophage inflammatory protein-3alpha is a novel serum marker for nasopharyngeal carcinoma detection and prediction of treatment outcomes. Clin Cancer Res 2008, 14:6979-6987
36. Chen KJ, Lin SZ, Zhou L, Xie HY, Zhou WH, Taki-Eldin A, Zheng SS: Selective recruitment of regulatory $T$ cell through CCR6-CCL2O in hepatocellular carcinoma fosters tumor progression and predicts poor prognosis. PLoS One 2011, 6:e24671

37. Xu L, Xu W, Qiu S, Xiong S: Enrichment of CCR6+Foxp3+ regulatory $T$ cells in the tumor mass correlates with impaired CD8+ T cell function and poor prognosis of breast cancer. Clin Immunol 2010, 135:466- 475

38. Oldham KA, Parsonage G, Bhatt RI, Wallace DMA, Deshmukh N, Chaudhri S, Adams DH, Lee SP: T lymphocyte recruitment into renal cell carcinoma tissue: a role for chemokine receptors CXCR3, CXCR6, CCR5, and CCR6. Eur Urol 2012, 61:385-394[ Epub 2011 Nov 4]

39. Baumforth KR, Birgersdotter A, Reynolds GM, Wei W, Kapatai G, Flavell JR, Kalk E, Piper K, Lee S, Machado L, Hadley K, Sundblad A, Sjoberg J, Bjorkholm M, Porwit AA, Yap LF, Teo S, Grundy RG, Young LS, Ernberg I, Woodman CB, Murray PG: Expression of the EpsteinBarr virus-encoded Epstein-Barr virus nuclear antigen 1 in Hodgkin's lymphoma cells mediates up-regulation of CCL20 and the migration of regulatory T cells. Am J Pathol 2008, 173:195-204 